Man and Nature

L'homme et la nature

\title{
What Represents in a Representation? A Question Concerning Michel Foucault's "Age Classique"
}

\section{James Creech}

\section{Volume 2, 1984}

URI : https://id.erudit.org/iderudit/1011807ar

DOI : https://doi.org/10.7202/1011807ar

Aller au sommaire du numéro

\section{Éditeur(s)}

Canadian Society for Eighteenth-Century Studies / Société canadienne d'étude du dix-huitième siècle

ISSN

0824-3298 (imprimé)

1927-8810 (numérique)

Découvrir la revue

Citer cet article

Creech, J. (1984). What Represents in a Representation? A Question Concerning Michel Foucault's "Age Classique". Man and Nature / L'homme et la nature, 2, 1-13. https://doi.org/10.7202/1011807ar

\section{Résumé de l'article}

Même pendant la période classique la représentation n'est pas de la transparence sans problèmes que Foucault lui attribue. Représantation implique re-présentation, donc différence; la représentation ne vaut jamais l'original. Cette inévitable différence produit des paradoxes épistémologiques qu'on examinera chez Platon et Locke et dans les écrits de D'Alembert sur l'Encyclopédie. On portera une attention particulière à « Ce que tout le monde sait sur l'expression, et quelque chose que tout le monde ne sait pas " par Diderot.
Copyright (C Canadian Society for Eighteenth-Century Studies / Sociéte canadienne d'étude du dix-huitième siècle, 1984
Ce document est protégé par la loi sur le droit d'auteur. L'utilisation des services d’Érudit (y compris la reproduction) est assujettie à sa politique d'utilisation que vous pouvez consulter en ligne.

https://apropos.erudit.org/fr/usagers/politique-dutilisation/ 


\title{
WHAT REPRESENTS IN A REPRESENTATION?
}

\section{A QUESTION CONCERNING MICHEL FOUCAULT'S}

\author{
"AGE CLASSIQUE"
}

James Creech

Representation is the essential element in Michel Foucault's definition of the classical "episteme" in Les Mots et les choses. ${ }^{1}$ Since I intend to call that analysis into question, I shall attempt a concise summary of what Foucault understands the nature and function of representation to have been during this period. What is necessarily dense about the summary will become clear in the specific applications that soon follow.

In Foucault's reading of the seventeenth and eighteenth centuries, signs were no longer part of the world, as they had been in the sixteenth century. In the classical age, signs are thought to represent the world in a separate but transparent medium whose privileged form is language ( $p$. 175). Language represents the particular as well as the general representability of all things. A particular use of a word to signify a thing is grounded in the overall substitutability of words for things in a relation of transparent adequation to the thing's identity.

Next, representations according to Foucault involve "analysis" of what they represent. The moment in which words and things are connected in a relation of transparent adequation naturally leads to an ordering of things and words among themselves according to identities and differences. The transparent relationship of identity automatically entails an incremental 
passage to increasingly different words and things which Foucault describes as a grid or a table of identities and differences. And again, the adequation, the transparent correspondence of the whole grid (language) and the totality of things, is the overarching identity upon which this system of knowledge rests. To know in the classical episteme is to represent in this fashion.

In an important sense, Foucault has formulated a convincing version of epistemological procedures in the seventeenth and eighteenth centuries. One is struck by the explanatory power of his analysis when "applied" to a variety of significant texts of the period. What follows are two examples of texts that it can serve to elucidate in an interesting way.

In the Discourse on Method, Descartes first lays out the four logical precepts for accepting or rejecting a thought, which could be summarized as follows:

1) the criterion of the thought's absolute and indubitable clarity and distinctness to the mind;

2) the necessary division of all complex thoughts into as many separate segments as possible;

3) the subsequent ordering of thoughts, going by increments from the simplest to the most complex;

4) the general necessity to enumerate and review thoughts so generally that nothing would be left out.

The "cogito" in the fourth section of the discourse is elaborated then in harmony with all these precepts. Descartes rejects as absolutely false anything in which the least doubt is imaginable, in harmony with the first precept requiring absolute clarity of any thought. This means that he rejects, supposedly at least, all sense experience, since it is sometimes erroneous and misleading. Furthermore, he rejects all former thoughts, since some of them can come to us in dreams and are therefore perhaps false. The only thought left is that the thinker, the doubter, the subject remains and cannot be doubted. "I think, therefore I am." This is the kernel of identity. As for the differentiated increments that follow, the immateriality of the rational soul, its immortality, the existence of God, etc. (the whole Cartesian system), each element is a specific representational thought, increasingly different from the first identity of "je" and intellect, but nevertheless grounded in it. The cogito, in Descartes, founds the grid of representation. It is, as it were, the navel of the system, the point of original contact and communication between representation and being.

In the Port Royal Grammar, Arnauld and Nicole display their cartesianism when they describe what it means to conceive an idea. Once the mind is granted its privileged intuition, then the representative series can extend in all directions: "On appelle concevoir la simple vue que nous avons des choses qui se présentent à notre esprit, comme lorsque nous nous représentons un soleil, une terre, un arbre, un rond, un quarré, la 
pensée, l'être."2 Between the mind and the world is now a transparent representational element, a language, through which one is given to know. It is an open-ended but mappable series of grids and tables of identities and differences--hence the emphasis on grammar.

Another example of the explanatory fecundity of Foucault's understanding of the period, this one mentioned specifically in Les Mots et les choses, is the Encyclopédie. For indeed, the Encyclopédie exemplifies the major feature of representation in the classical age in that it is based on the particular status accorded to language. Foucault points out that the work's organization owes nothing to an order believed to be intrinsic to the knowledge that it represents. Rather it is determined by the alphabet, an arbitrary order existing only within language. The text's order is accommodated within the very space opened by words, within the language element itself ( $p .88)$. Through that space language is put into relation with the universal and to being (p. 86) and thus determines the organization of a work that attempted to represent the universal. Although modern usage has consecrated the appellation "Encyclopédie," its original name bears witness to a different emphasis which is pertinent to Foucault's version of its status in relation to language: it is conceived as a "Dictionnaire Encyclopédique."

In his Discours préliminaire, D'Alembert's language resonates with Foucault's analysis in remarkable ways. "La nature. . . n'est composée que d'individus qui sont l'objet primitif de nos sensations et de nos perceptions directes. Nous remarquons, à la vérité, dans ces individus, des propriétés communes par lesquelles nous les comparons, et des propriétés dissemblables par lesquelles nous les discernons. • . ."3 Similarity and difference are indeed the bases for the organization of all "things" in the Encyclopédie into a representational system.

Similar confirmation could be located in other texts by Descartes and D'Alembert, not to mention numerous other writers, many of which are of course to be found mentioned in Les Mots et les choses. But in fact, that is not my purpose here. It seems to me that at this juncture it is more important to raise another sort of issue, one which will qualify Foucault's argument more than it confirms it. Stated succinctly: can a historical period open and close a relation to "representation"--simply, serenely, unproblematically? If I begin by recognizing the significance of Foucault's analysis within the closed space of the "classical age" that it establishes for itself, it is in order to counterbalance the critique which follows. For it needs to be pointed out that in our tradition the question of "representation" has particular properties that make it impossible to appropriate, as does Foucault, to a particular historical period.

For representation itself has a long history. The question of representation is already at work in Democritus, in Plato and Aristotle, in scholasticism, in Locke, Hegel, Freud. . Any list would be impressive more for the names it leaves out than for those it includes. By saying that representation has a history, I am granting that it is ordered according to different protocols in different historical moments, by different societies, by different thinkers, in response to different ideological necessities. 
Granted. But it is also a-historical. In all aspects of the Platonic tradition (in which, at this level of generality, one must include all Western Thought), representation has perhaps been the question.

What is constant and a-historical about the question of representation is implied in the very form of the word. Representation has always been re-presentation, as Jacques Derrida has reminded us many times. 4 Representation implies a return to presence of something which once was present and now--at the moment of its re-presentation--is not. The presence to which the object of representation is restored is both a temporal and spatial presence; the object is once again present here and now. That logic comes, as it were, with the word.

Whatever marks a representational presence as a return to presence--as a second presence of its object--is therefore something like a "negative mark." It is a reminder that the representation is not the object which it strives to re-present. It is only a representation. Representation fails, in this sense, because it does not really render its object present, so fully present that the first presence (the so-called original presence) is entirely subsumed or obliterated by its second presence. So, for example, "je" does not remain the same "je" when re-presented in the phrase "je pense, donc je suis." The two are not absolutely equal. Instead, the representation remains secondary. That is even the condition of possibility for it to represent at all. In order to be efficacious, to succeed, it must fail in just this way. It must remain a "concept endeuillé," in mourning for the loss of its "original" object. 6 Such nostalgia is based however on a fiction, for the representation never really possessed its object, and came into being only on the condition that its object be originally differentiated from it. 7 Differentiation is a basic feature in representation, even representation of identity.

This is the irreducible paradox that, a-historically, the question of representation brings with it, even in its historically specific forms. And how could it be otherwise, since history is itself a representation of its object, both representation and object, such that representation taken as an issue in itself necessarily transcends the limits that any historical project, properly speaking, could impose upon it. As an example of what I mean, here are four different "moments" in representation's history in which a certain sameness emerges beneath the obvious difference and specificity of each.

Plato saw the world of appearances as falling short of ideal reality, as "striving" or "longing" for the ideal identity that appearances represent imperfectly. In the "Phaedo," Socrates argues, as he does elsewhere, that all knowledge is recollection of knowledge that we had previously but have forgotten. We learn when we experience or perceive things in the phenomenal world through our senses. But what we learn from such experiences is ultimately derivative of other things which the objects of perception and knowledge are not. What we learn from the world of shadows is only a recollection of the ideal world, which the phenomena, in some sense at least, represent. 
Here is one of Socrates' arguments from the "Phaedo." His interlocutor in this part of the dialogue is Simmias.

Socrates: The knowledge of a lyre is not the same as the knowledge of a man?

Simmias: True.

Soc: And yet what is the feeling of lovers when they recognize a lyre, or a garment, or anything else which the beloved has been in the habit of using? Do not they, from knowing the lyre, form in the mind's eye an image of the youth to whom the lyre belongs? And this is recollection. In like manner anyone who sees Simmias may remember Cebes; and there are endless examples of the same thing.

Sim: Endless, indeed.

Soc: And recollection is most commonly a process of recovering that which has been already forgotten through time and inattention.

Sim: Very true. [... $]$

Soc: And in all these cases, the recollection may be derived from things either like or unlike?

Sim: It may be.

Soc: And when the recollection is derived from like things, then another consideration is sure to arise, which is--whether the likeness in any degree falls short or not of that which is recollected?

Sim: Very true.

Soc: And shall we proceed a step further, and affirm that there is such a thing as equality, not of one piece of wood or stone with another, but that, over and above this there is absolute equality? Shall we say so?

Sim: Say so, yes, replied Simmias, and swear to it, with all the confidence in life.

The outcome of this argument, which I won't retrace fully here, is this: "Whenever from seeing one thing you conceived another, whether like or unlike, there must surely have been an act of recollection" (p. 215). From the recollection of one thing by perception of another thing we experience a kind of equality of those two things. (In the sense that $x=y_{\text {.) }}$ But we also know that those things are not the same, even if they are "like" each other. We know at the same time that $x$ is not $y$. One piece of wood or stone may be of equal size and shape as another, but we also perceive their inequality, which is to say, their difference from each other. From the equality ( $I$ would call it "representationality") of two things which are different, we gather another equality, not the same as the equality of different things, but of things that are absolutely equal, conjoined in an absolute presence to self, not through a re-presentation of $\mathrm{x}$ in $\mathrm{y}$. (This will be Socrates' qualification of the realm of ideal essences.) In this way the phenomenal gives us to "recollect" the noumenal. "From the senses then," concludes Socrates, "is derived the knowledge that all sensible things aim at an absolute equality of which they fall short" (p. 216). 
Representation of a thing by another thing (similar or dissimilar) is for Plato a double representation: $x$ represents but is not $y$, as $I$ said; and secondly: the representationality of $x$ and $y$ represents but is not another, ideal representationality of things in absolute equality, that is, in a relationship of absolute indifferentiation and identity.

(Let me place a cautionary restriction on what I have said here. Plato's is not strictly speaking an epistemology in the modern sense, based on a theory of representation understood as such. I am necessarily leaving out many important qualifications here, not to mention permutations of the problem found in Aristotle. But I maintain that Plato is ultimately involved in a question of gepresentation that does communicate with the modern form of the problem. ${ }^{9}$ )

But to return to the present argument: $x=y$, Lyre $=$ (metonymically) Simmias. These associations are produced by a copula that can be understood as performing a function that we think of as representational. The negative "falling short" of terms "coupled" in this way, for Plato, implied a copula of a different and ideal sort. Ideality is given to our knowledge then in the very difference from ideality we can intuit in the phenomena. In other words, the notion of representation in Plato brings with it the duplicity described a moment ago: something is made present again, but present in such a fashion as to remind us of what remains absent or different, ideal, something to which representation remains inadequate. Adequatio and inadequatio are conjoined. Representation enjoys no simple transparency of the sort that Foucault finds in the eighteenth century. In Plato there is difference between representation and represented; yet, somehow, the link between them is given in their difference. Representation constitutes a problem that philosophical discourse sets out to resolve.

Locke is in a different position but the question of representation disseminates effects that put his writing in communication with Plato. Locke's is an epistemology based on the capacity of the senses accurately to represent what he calls primary and secondary ideas to the mind. If one looks for some clue to the precise nature of the copula of representation in the Lockean system, one comes upon a very curious explanation in the Essay Concerning Human Understanding which I reproduce here in abridged form. For Locke there is no intrinsic link, or basis for an intrinsic link, between the phenomenal world and ideas in the mind. It is specifically in this that he is, in fact, anti-platonistic (in ordinary, intellectual-historical terms). Here is the passage, from Book II:

The next thing is to consider how bodies produce ideas in us; and that is manifestly by impulse ("impulse" here means motion). . . If then external objects be not united to our minds and yet we perceive these original qualities in them "original" is italicized by Locke). . it is evident that some motion must be thence continued by our nerves. - to the brains or seat of sensation, there to produce in our minds the particular ideas we have of them. And since the extension, figure, number and motion of bodies. . may be perceived at a distance by the sight, it is evident /that/ some singly imperceptible bodies must come from them to the eyes, and thereby convey to the brain some motion; which produces these ideas we have of them in us. 10 
In the next section on how we derive ideas of secondary qualities, he is even more explicit, and interesting, for our purposes here: we perceive secondary qualities thanks to "the operation of insensible particles on our senses." These particles cannot themselves be perceived, but they cause perceptions of an object to occur in the sense organs, and from these, to become ideas in the brain. They mediate, in other words, between perceptible object and brain, but are themselves imperceptible. Locke's entire sensationalist epistemology, where nothing is in the mind that was not first in the senses, hinges on this copula function performed by in-sensible particles. But Locke does not, cannot, really explain them. The particles are an aberrancy in the system. For he is, according to his own precepts, speaking of something of which he has no idea--because he cannot perceive these particles by any sense--no more than he could have an idea of those abstract "substances" so cherished by aristotelian scholasticism which he discards as abstractions for just that reason: they cannot be perceived. What the particles do for Locke's representational epistemology (and the reason he posits them) is to guarantee the two contradictory relations of representation and represented that I earlier claimed were implicit in the very word: first, that the object be re-presented accurately in the senses, that the representation be a return to presence of the "original qualities" (thus a function of identity); and secondly, that the object remain different from the mind's perception, extrinsic and thus reproducible, only a representation. Locke's particles, at least in these important ways, serve the function served in Plato by the difference of $x$ and $y$ and the absolute (divine) equality that it gives us to know. And as if to prove the point, Locke also resorts to God as a means of justifying the present argument. "Let us suppose, at present," he writes, "that the different motions and figures, bulk and number of such particles, affecting the several organs of our senses, produce in us those different sensations which we have from the colors and smells of bodies. . . It being no more impossible to conceive that God should annex such ideas to such motions, with which they have no similitude, than that he should annex the idea of pain to the motion of a piece of steel dividing our flesh, with which that idea hath no resemblance" (pp. 172-173). What is revealed in this appeal to divine, ultimate authority is Locke's own discomfort with the theory of imperceptible particles. They are essential to his representational epistemology. They explain what represents in sense representation. But they radically contradict the empiricism on which Locke's notion of a simple, transparent representation was based. They exemplify the most basic difficulty that his philosophical discourse, like that of Plato, is setting out to resolve.

If we return to D'Alembert's Discours préliminaire, indeed to the very pages which served above the exemplify Foucault's success in describing the age's relation to representation, we shall discover a moment that is similar to Locke's discussion of insensible particles.

The Encyclopédie is ordered on the basis of an alphabetical listing of words-things. Each word is followed by an article defining the thing. The whole, however, is ordered according to what Diderot and D'Alembert call, after Bacon, an encyclopedic "tree." For readers of Foucault, the encyclopedic tree can easily be understood as a version of the grid of differences and similarities, as we saw above. But if we read more closely we discover 
a perception by D'Alembert that Foucault's analysis does not account for, namely, a sense of impossibility, of obstacle, that the arborescent system brings with it. (In D'Alembert's Discours préliminaire it is only mentioned; in Diderot's article "Encyclopédie," it is rife.) Here is the pertinent passage in D'Alembert:

Quoique l'histoire philosophique que nous venons de donner de l'origine de nos idées, soit fort utile pour faciliter un pareil travail, il ne faut pas croire que l'arbre encyclopédique doive ni puisse même être servilement assujeti à cette histoire. Le système général des sciences et des arts est une espèce de labyrinthe, de chemin tortueux, où l'esprit s'engage sans trop connaitre la route qu'il doit tenir ( $\mathrm{pp}$. 43-44, my emphasis).

In principle--the principle analyzed by Foucault, no doubt--there is an editorial point of view from which the "labyrinth" is transformed into a "mappemonde," allowing us to perceive at a glance all the similarities and differences of the world, to "distinguer les branches générales des connaissances humaines, les points qui les séparent ou qui les unissent. . ." (p. 45). But D'Alembert explicitly recognizes that such a point of view is only a "projection": "On peut donc imaginer autant de systèmes différents de la connaissance humaine, que de mappemondes de différentes projections" ( $p .45$, my emphasis).

Nor is this the only perturbation in transparent representationality. For the best point of view from which to "project" the encyclopedic tree is said to be one which allows the greatest number of differences and similarities--of connections--to appear. D'Alembert immediately raises a basic question concerning such a point of view: "Mais, peut-on se flatter de le saisir?" ( $p$. 45). D'Alembert continues, with implicit reference to Locke:

La nature. - .n'est composée que d'individus qui sont l'object primitif de nos sensations et de nos perceptions directes. Nous remarquons, à la vérité, dans ces individus, des propriétés communes par lesquelles nous les comparons, et des propriétés dissemblables par lesquelles nous les discernons. . . Mais souvent tel objet qui, par une ou plusieurs de ses propriétés, a été placé dans une classe tient à une autre classe par d'autres propriétés, et aurait pu tout aussi bien y avoir place. Il reste donc nécessairement de l'arbitraire dans la division générale. ( $\mathrm{pp}$. 45-46)

Clearly, this is an instance in which an unstated but operative epistemological convention calls for representation of differences and similarities in the manner described by Foucault. But even as D'Alembert prescribes it, he in effect recognizes its necessary failure. And there is no transcendency to come to the rescue, as there was for Plato.

But this obstacle is not the only one, nor the most serious.

From an ideal point of view--only a projection, of course--there would be no categorical divisions of the things represented in the Encyclopedie. The most natural arrangement (representing things in the Encyclopédie just 
as they are in "nature") would be a chain in which all things would be bound together by incremental links. But the possibility of this ideal system for representing reality is also ruled out, and in terms which are by now familiar to us.

L'arrangement le plus naturel serait celui où les objets se succéderaient par les nuances insensibles qui servent tout à la fois à les séparer et à les unir. Mais le petit nombre d'êtres qui nous sont connus, ne nous permet pas de marquer ces nuances. L'univers n'est qu'un vaste océan, sur la surface duquel nous apercevons quelques iles plus ou moins grandes, dont la liaison avec le continent nous est cachée ( $p .46$, my emphasis).

As did Locke, D'Alembert begins by insisting that the "object" to be represented--reality, "nature"--is composed of entities "qui sont l'objet primitif de nos sensations et de nos perceptions directes." We see similarities and differences in these objects that are to be represented. But that which unites and separates these objects of our direct perception cannot be perceived. If one cannot perceive these "nuances insensibles" that make unity and difference, then one cannot represent according to Foucault's grid. And this is precisely the problem which D'Alembert perceives.

Before moving on to Diderot, a recapitulation of the argument is warranted, and with it, a few preliminary conclusions. The question is: what represents in a representation? Foucault claims that the epistemological protocols of the modern classical age conceived of representation, in the mode of language, as a transparent medium by which things could be tightly systematized according to their identities and differences. I have claimed that, a-historically, representation brings with it certain paradoxes, certain effects of difference. I have tried to show four historical moments, four different cases of representation, in which an effort to grapple with the a-historical paradox is legible. The conclusion which I have been implying up to now, but will formulate more explicitly here, is this: representation (in Plato's term: "whenever from seeing one thing you conceive another")--brings with it the problem of similarity and difference; indeed this question fuels epistemological systems; it is what those systems are trying to accomodate, but the effort itself is always incommodious; and, with reference to Foucault's reading of the seventeenth and eighteenth centuries, only a particular and strategic blindness could prompt him to argue for a serene, unproblematic and transparent representational element, even in a past, historic mode. Yet, that is what Foucault repeatedly claims in such formulations as this: "Le continuum de la représentation et de l'être, une ontologie définie négativement comme absence de néant, une représentabilité générale de l'être, et l'être manifesté par la présence de la représentation,--tout ceci fait partie de la configuration d'ensemble de l'épistémè classique" (p. 219). But, as I've said, "the being manifested by the presence of representation" is not manifested simply by a simple presence. And here is where Diderot enters my argument.

He is a major figure of what Foucault calls the classical age. And the problem of representation never ceases to inhabit his writing on virtually all subjects, even though he does not often discuss it explicitly. In 
order really to make the point fully, one would have to present an analysis of Diderot's major philosophical texts that deal explicitly with epistemological issues similar to those I have signaled in Plato, Descartes, D'Alembert and Locke. ( I am thinking explicitly of the Lettre sur les aveugles, the Lettre sur les sourds et muets, and Le Rêve de D'Alembert.) I have chosen a much smaller text that, as will become obvious, communicates with some of the same issues. It is a disarmingly simple text. It comes in one of his Essais sur la peinture (1765), entitled "Ce que tout le monde sait sur l'expression, et quelque chose que tout le monde ne sait pas."ll The question of artistic "expression" organizes the essay around a larger question of representation generally.

The opening part of this text recalls Du Bos or Batteux, the most classical mimetic traditions, in such expressions as these: "Chaque état de la vie a son caractère propre et son expression" ( $p .65$ ). The essay's very first sentence reads, "L'expression est en général l'image d'un sentiment" (p. 63). This is no doubt the part of the essay that corresponds to the first clause of the title: "Ce que tout le monde sait sur l'expression. . . "

Here is the beginning of the text which, in my view, corresponds to the second clause of the title: ". . quelque chose que tout le monde ne sait pas."

Je ne saurais résister. Il faut absolument, mon ami, que je vous entretienne ici de l'action et de la réaction du poète sur le statuaire ou le peintre; du statuaire sur le poète; et de l'un et de l'autre sur les êtres tant animés qu'inanimés de la nature. Je rajeunis de deux mille ans pour vous exposer comment, dans les temps anciens, ces artistes influaient réciproquement les uns sur les autres; comment ils influaient sur la nature même et lui donnaient une empreinte divine. Homère avait dit que Jupiter ébranlait l'Olympe du seul mouvement de ses noirs sourcils. C'est le théologien qui avait parlé; et voilà la tête que le marbre exposé dans un temple avait à montrer à l'adorateur prosterné. La cervelle du sculpteur s'échauffait; et il ne prenait la terre molle et l'ébauchoir que quand il avait conçu l'image orthodoxe. Le poète avait consacré les beaux pieds de Thétis, et ces pieds étaient de foi; la gorge ravissante de Vénus, et cette gorge était de foi; les épaules charmantes d'Apollon, et ces épaules étaient de foi. . . Le peuple s'attendait à retrouver sur les autels ses dieux et ses déesses avec les charmes caractéristiques de son catéchisme. Le théologien ou le poète les avait désignés, et le statuaire n'avait garde d'y manquer. . . (pp. 69-70)

When the poets described the physical attributes of the gods they created orthodox expectations that subsequent visual representations were obliged to respect. Because of poetic description, Thetis's lovely feet, Venus's breast, Apollo's shoulders all existed, in some sense, as models to be represented. But they only existed as belief--"de foi." Sculptors were in an impossible situation when they carved such divine images. The pious Athenians would have ridiculed a statue of Hercules with slack shoulders, but still no one knew what a proper statue of a god should actually resemble. There was no visual model of divinity, and, as we shall see, the poet 
had "revealed" nothing, nor had he created belief. The painter and the sculptor had represented nothing more divine than quite ordinary, profane qualities, borrowed from nature. The feet, bosom and shoulders with which the artist represented the gods were copied mimetically. They were only profane, human features manifesting no intrinsic divinity. Precisely insofar as such representations were mimetic, they were un-representative of the divine model they were supposed to "express."

At this point of the explanation, the artist has completed his work and the faithful have seen it in the temple. In a realm of representational transparency, that should be the end of it. But in Diderot's analysis, the artist's work has not yet "expressed" the character of the orthodox divinity that the viewers had anticipated. That is still for a future moment. It poses a question, a problem, that esthetic analysis will have to resolve:

Qu'arrivait-il de là,--car, après tout, le poète n'avait rien révélé ni fait croire; le peintre et le sculpteur n'avaient représenté que des qualités empruntées de la nature? C'est que, quand, au sortir du temple, le peuple venait à reconnaitre ces qualités dans quelques individus, il en était bien autrement touché. La femme avait fourni ses pieds à Thétis, sa gorge à Vénus; la déesse les lui rendait, mais les lui rendait sanctifiés, divinisés. L'homme avait fourni à Appollon ses épaules, . . mais Apollon . . les lui rendaient sanctifiés, divinisés.

Lorsque quelque circonstance permanente, quelquefois même passagère, a associé certaines idées dans la tête des peuples, elles ne s'y séparent plus; et s'il arrivait à un libertin de retrouver sa maitresse sur l'autel de Vénus, parce qu'en effet c'était elle, un dévot n'en était pas moins porté à révérer les épaules de son dieu sur le dos d'un mortel, quel qu'il fût (pp. 70-71, my emphasis).

When, at the exit of the temple people recognized those qualities in the bodies of their fellow citizens, they were affected by them in quite another fashion--"le peuple... en était bien autrement touché." At that moment, there is the reciprocal imprint of art on nature and of nature on art that Diderot mentions at the outset of his digression. The libertine finds himself just as apt to revere the artistic image of his mistress on the sacred altar as a pious believer was to revere the image of a goddess which he now discovers in a mortal woman. In nude competitions, "il y avait, sans qu'ils s'en doutassent, dans le tribut d'admiration qu'ils rendaient à la beauté, une teinte mêlée de sacré et de profane, je ne sais quel mélange bizarre de libertinage et de dévotion" (p. 71). The lover who, while embracing his mistress, addressed her as a goddess spoke truly. "C'est qu' il jouissait réellement de l'objet de son adoration et de l'adoration nationale" (p. 71 ).

Once one tries to understand it clearly, the simplicity of this clever mythical etiology dissappears. Diderot, in a certain sense, is miming the Platonic traditon, and radically deforming it at the same time. As in Plato, when we see a work of art, a statue, it moves us and is beautiful 
to us because through it we are given to recollect the ideal of beauty (here: of divinity) that it represents phenomenally. But in the present text, there is no unidirectional representation or "expression" of divine character, from a model (ideal or otherwise) to its secondary representation, if for no other reason than that its "empreinte" marks both the natural body and its artistic representation simultaneously and at a particular moment. Diderot is not describing an instance of nature imitating art or any other simple reversal of traditional mimetic priorities.l2 Rather, he is analyzing a "mélange bizarre" of antithetical qualities: the sacred and the profane, devotion and debauchery. When the people, at the threshold of the temple, saw features of the gods in their fellow man, "il en était bien autre-ment touché," touched by the alterity that is now perceptible both in the human model and in the representation on the altar. Each now bears upon itself the imprint, not only of transparent representation in the guise of mimetic similarity--which was never in question-but of a liminal differentiation. Both statue and body have entered general representationality. They can diacritically signify many gods, any lover ("quel qu'il fût"), and mark them as beautiful or divine--as ideal. The threshold of the temple, the "sortir" defining the sacred and the secular world in categorical opposition to each other, has now opened within representation and model as well. That is the nature of the "empreinte." Because of it, both body and statue are now "reft" by metaphor, meaning both "robbed" of simple presence and "split" between presence and representation. "Ma reine, ma souveraine, ma déesse" ( $p .71$ ), one now may say to mortal women, and moreover, it is true.

Foucault's estimation of the grid of representation as an intermediary transparency "looking down" upon things, as it were, dividing them into discrete categories of identity and difference--for all its accuracy and explanatory power--cannot accommodate a moment such as that described in this little fantasy of Diderot's. In it, the representation of a thing to the knowing subject is produced very precisely by the undecidability of its identity and its difference.

The question for Diderot is again, albeit in esthetic terms, "what represents in a representation?" and again, difference and identity, presence and absence, connection and disconnection--all emerge as a part of the problem that representation brings with it. Diderot's text communicates in this way with the texts of his predecessors in a matrix of concerns underlying them all. But at the same time, Diderot's text differentiates itself from the others by not subordinating difference to any form of identity that derives from other givens--from divine intervention or transcendence, from an ideal editorial viewpoint able to perceive the identity of a whole to which our eyes are blind. I am not sure whether we have ears to hear or eyes to read such a text which answers so undecidably to the question of what represents in a representation. But it is beginning here, with his own identity/difference in relation to the (a-)history of representation, that Diderot needs to be read. Foucault's archeology of the eighteenth century does not open the possibility of such reading. 
NOTES

Les Mots et les choses (Paris: Gallimard, 1966); all further references will be given in the text.

Quoted by Marion Hobson in "La Lettre sur les Sourds et muets de Diderot: Labyrinthe et langage," Semiotica, 16, no. 4 (1976), 304.

Oeuvres Complètes (Geneva: Slatkine Reprints, 1967), Vol. I, pp. 4446. All further references are given in the text.

This in many texts, perhaps most notably in De la Grammatologie (Paris: Minuit, 1967), and "La Différance," in Marges (Paris: Minuit, 1972), pp. 1-29.

By "object" I mean referent or signified, one or both. As for the logic that comes with the word: "Représenter, empr. des mots lat. repraesentare 'rendre présent, reproduire,' repraesentaio 'action de mettre sous les yeux'. . . (de praesens 'présent')." Dictionnaire étymologique de la langue francaise, eds. 0 . Bloch and $W$. von Wartburg (Paris: P.U.F., 1932), p. 548.

I owe this characterization of the concept to a conversation with Michel de Certeau.

See Derrida, "La Différance": "La différance, c'est ce qui fait que le mouvement de la signification n'est possible que si chaque élément dit 'présent,' apparaissant sur la scène de la présence, se rapporte à autre chose que lui-même, gardant en lui la marque de l'élément passé et se laissant déjà creuser par la marque de son rapport à l'élément futur, la trace ne se rapportant pas moins à ce qu'on appelle le futur qu'à ce qu'on appelle le passé, et continuant ce qu'on appelle le présent par ce rapport même à ce qui n'est pas lui: absolument pas lui..." (p. 13)

"The Phaedo," transl. B. Jowett, in The Dialogues of Plato (Oxford: Oxford University Press, 1926), Vol. II, pp. 214-215. Further references are given in the text.

9 For a general treatment of the problem, see Richard Rorty, Philosophy and the Mirror of Nature (Princeton: Princeton University Press, 1979).

10 An Essay Concerning Human Understanding, ed. Alexander C. Fraser (New York: Dover Publications, Inc., 1959), Vol. I, pp. 171-172. All further references will be given in the text.

11 Essais sur la peinture, ed. Roland Desné (Paris: Editions Sociales, 1955). All references will be given in the text.

12 For a contrary opinion, to which I take exception, see Derrida, "La Double séance," in La Dissémination (Paris: Seuil, 1972), p. 216, note 12 . 